\title{
We Can Thank Harvey Weinstein for Doing What Congress and the Supreme Court Failed to Do
}

Cornell Hospitality Quarterly

2018, Vol. 59(2) 174-188

(C) The Author(s) 2018

Reprints and permissions:

sagepub.com/journalsPermissions.nav DOI: $10.1177 / 1938965518761993$

journals.sagepub.com/home/cqx

@SAGE

\author{
David Sherwyn' and Paul Wagner ${ }^{2}$
}

\begin{abstract}
While the years 2017 and 2018 will be remembered for numerous geo political and social movements, any retrospective of this time will include the issue of sexual harassment and the corresponding "Me Too" movement. In this time, sexual harassment has transformed from a workplace legal concept to an issue that is defining the fabric of the country. While no one could persuasively argue that sexual harassment has not expanded from its legal roots to a movement that transcends the law, the fact is that the concept is rooted and adjudicated in law. Sadly, the commentators and the popular press often ignore or misstate the law. This creates a dangerous culture where the public is misinformed of their rights and responsibilities. More troubling, is the fact that there are serious problems with the law that need to be understand and, we contend, changed, in order for the entire problem to be eliminated, or, at least, mitigated. This paper explains the law with regard to what constitutes sexual harassment and when the employer is liable, identifies the problems, and proposes a fix so that we can create a future workplace where the authors' five daughters (between them) and the rest of their generation will be able to honestly not raise their hands and not have to say: "Me Too!"
\end{abstract}

\section{Keywords}

labor relations, human resources, hospitality education, other, other legal issues, legal issues, ethics, organizational behavior, leadership, organizational behavior

The fall of 2017 will one day be remembered as the point in time when a Hollywood producer's grotesque actions opened the floodgates and changed the entire sexual harassment landscape in the United States. As anyone who read a newspaper, watched cable news, or followed President Trump's twitter account knows, on October 5, 2017, the New York Times published an article alleging that Mr. Weinstein had engaged in "sexual harassment and unwanted touching" with female employees and other women seeking film roles or to begin or further a Hollywood career. The response was damning and swift. Although Weinstein did deny some of the claims, he did not, like then-presidential candidate Donald Trump, deny all the allegations or attack the accusers. Instead, he stated the following:

I appreciate the way I've behaved with colleagues in the past has caused a lot of pain, and I sincerely apologize for it. Though I'm trying to do better, I know I have a long way to go.

He added that he was working with therapists and planning to take a leave of absence to "deal with this issue head on."

The reaction to Weinstein's tepid response was sharphe was condemned by colleagues at his movie studio, the entire film industry, the media, politicians, and even by his own brother. Although he denied subsequent rape allegations, the general consensus was utter contempt for Weinstein and his career and reputation was destroyed overnight.

The sexual harassment fallout did not, however, end with Weinstein. A number of well-known men including, but not limited to, NPR Vice President and former New York Times Washington Bureau Chief, Michael Oreskes; actor Kevin Spacey; political reporter Mark Halprin; celebratory chef John Besh; technology consultant Robert Scoble; writer and director James Toback; Amazon Studio Programming Chief Roy Price; fashion photographer Terry Richardson; and Brookings Institute Senior Fellow Leon Wieseltier were soon "outed" as sexual harassers and their status and careers were placed in jeopardy, if not instantly dismantled. Next, came the Roy Moore and Al Franken controversies, and

\footnotetext{
'Ithaca, NY, USA

${ }^{2}$ Cornell University, Ithaca, NY, USA
}

\section{Corresponding Author:}

David Sherwyn, 54I Statler Hall, Ithaca, NY I4850, USA.

Email: dss 18@cornell.edu 
sexual harassment now dominated the headlines and the majority of cable news airtime. As expected, the well-known sexual harassing behaviors of former President Bill Clinton and current President Donald Trump were resurrected and the controversies surrounding both men became even more heated and polarizing.

Like Hollywood and politics, the hospitality industry did not escape the sexual harassment scorn. A November 4, 2017, article in the New York Post exposed the New York City restaurant community as a hot bed of sexual harassment allegations. ${ }^{1,4}$ The article cited a study by the Restaurant Opportunity Commission (receiver operating characteristic curve $[R O C]$ ), which found that $66 \%$ of female and more than half of male restaurant employees reported having been sexually harassed by managers, and $80 \%$ of women and $70 \%$ of men said they were victimized by coworkers. Next, came the creation of a new website, https://www.eater. com/2017/11/1/16572850/send-secure-tips-to-eater, a forum for restaurant employees to accuse supervisors, coworkers, and guests of sexual harassment. The website does not investigate or scrutinize accusations consistent with basic notions of due process, but merely posts the accusations for all to see without any opportunity for the accused to respond.

The Weinstein accusations, admissions, and the subsequent accusations against other prominent men through the media, including the Eater website, have fundamentally altered the sexual harassment landscape in the United States without any likely change in law or policy. Of course, this could be a short-term trend explained by a rapid exposure of abhorrent behavior by powerful men, starting with the release of the Access Hollywood tape during the 2016 presidential campaign. However, this could be just the beginning of a phenomenon of trying allegations of sexual harassment in the court of public opinion because of the conspicuous lack of clear guidance under federal and state law to employers on how to identify, punish, and ultimately prevent sexual harassment in the workplace. The current state of the law in this area is a mishmash of competing and often contradictory edicts because sexual harassment law was authored by a law professor and an administrative agency and codified by courts that, because of their limited authority, were restricted by a statute in which Congress never intended to prohibit this type of conduct, resulting in a body of case law with so many contradictions, absurdities, anomalies, and delays that employees, employers, lawyers, judges, and the general public have been left confused and frustrated while harassers have been left unchecked, if not emboldened. With such an ineffective legal mechanism to thwart harassment, victims and advocates naturally, and predictably, have resorted to a new way of attacking the problem: the Internet and the media. The problem with "litigating" by media is that the law and the standards are lost in the hype and controversy. Although this makes for high ratings, intense discussions, and,
Table 1.

Descriptive Statistics of gender and tenure of sexual harassment complainants. ${ }^{68}$

\begin{tabular}{ll} 
Employee & \\
\hline Sex & \\
Male & .05 \\
Female & .95 \\
Tenure & \\
$0-6$ months & .15 \\
6 months to I year & .37 \\
I-5 years & .27 \\
$5-10$ years & .14 \\
$>10$ years & .05 \\
\hline
\end{tabular}

hopefully, changed behaviors, it does not provide adequate guidance to employers who seek to create a workplace free from harassment.

The purpose of this article is to present the current state of sexual harassment law and the procedures used to enforce it, explain why it is so problematic, outline what should be done to fix it, and then explain what employers should do to deal with what appears to be the new normal.

\section{The Law of Sexual Harassment}

The first step in explaining the law of sexual harassment is to emphasize that there is no federal statute that prohibits or even addresses sexual harassment in the workplace. Scholars generally agree, that when enacting Title VII of the Civil Rights Act of 1964, Congress did not contemplate that the statute's prohibition against discrimination based on sex would create a cause of action for employees who were subjected to unwanted sexual advances without suffering any tangible loss. ${ }^{2}$ In fact, the origins of the legal prohibition against sexual harassment are generally attributed to Professor Catherine MacKinnon.

In 1979, Professor MacKinnon coined the term "sexual harassment," and thereby fueled the creation of a cause of action when she published the book Sexual Harassment of Working Women. MacKinnon defined sexual harassment in its broadest sense, as the "unwanted imposition of sexual requirements in the context of a relationship of unequal power." ${ }^{3}$ The influence of her work on both courts and scholars was profound. ${ }^{5}$

In 1980, the Equal Employment Opportunity Commission ("EEOC") expanded its guidelines on "Discrimination Because of Sex Under Title VII" to include sexual harassment. ${ }^{6}$ After the EEOC published its guidelines, courts routinely held that a hostile environment of sexual harassment did, in fact, constitute a cause of action. ${ }^{7}$ In 1986, in Meritor Savings Bank v. Vinson, ${ }^{8}$ the Court put to rest any lingering questions concerning the legal efficacy of MacKinnon's hostile environment theory as a civil cause of action. 
Table 2.

\section{Descriptive Statistics About Harassing Conduct. ${ }^{69}$}

\begin{tabular}{lc}
\hline Variable & Proportion \\
\hline Harassment_Location & \\
Workplace only & .84 \\
Workplace and work events & .04 \\
Workplace and social events & .07 \\
All three & .06 \\
Harassment_Conduct & \\
Derogatory names generally & .11 \\
Insults directed to plaintiff & .17 \\
Comments about appearance & .38 \\
Sexually charged comments, generally & .73 \\
Sexual gestures & .16 \\
Written sexual comments & .03 \\
Love letters to plaintiff & .03 \\
Sexual contact & .54 \\
Nonsexual contact & .37 \\
Requests for dates & .19 \\
Requests for sexual favors & .37 \\
Displaying pornographic materials & .07 \\
Sexual assault & .09 \\
Nonsexual, gender-related behavior & .08 \\
Harassment_Duration & .03 \\
One or more isolated incidents & .19 \\
<I month & .03 \\
I-6 months & .12 \\
6 months to I year & .01 \\
I-5 years & .42 \\
>5 years & .21 \\
Delay_Length & .31 \\
<I month & .05 \\
I-6 months & \\
I-5 years & \\
\hline
\end{tabular}

In relatively short opinion, the Meritor Court (a) established sexual harassment as a violation of Title VII; (b) held that two types of sexual harassment could be pleadquid pro quo (this for that), and hostile environment; and (c) provided a basis for employer liability using principles of agency law. The Supreme Court created a completely new cause of action without any clear legislative guidance or input. Although the definition of quid pro quo harassment seemed relatively straightforward, hostile environment sexual harassment was fraught with uncertainty and ambiguity.

As sexual harassment hostile environment cases made their way up the judicial food chain, different circuits began to create different rules with regard to hostile environment. Specifically, courts held that the conduct must (a) be sexual, (b) be unwelcome, (c) be severe or pervasive, (d) be abusive or hostile, (e) be because of sex, and (f) result in psychological damage. The first four of the six standards were fairly consistent; Standards e and f, however, created problems.

The requirement that the harassment cause psychological damage created the first controversy. The Sixth Circuit, ${ }^{9}$ the Eleventh Circuit, ${ }^{10}$ and the Federal Circuit ${ }^{11}$ each held that a plaintiff must prove psychological damage to prove hostile environment. The Ninth Circuit rejected this standard. ${ }^{12}$ In Harris v. Forklife Systems, Inc., the Supreme Court rejected the psychological damage requirement and defined sexual harassment as "sufficiently severe or pervasive to alter the conditions of the victim's employment and create an abusive environment ..." The Court also held that the conduct must be sufficiently severe or pervasive to create both an objectively and subjectively hostile or abusive environment - that is, the conduct must be severe or pervasive to the average reasonable person, and also severe or pervasive to the actual plaintiff. In his concurrence, Justice Scalia noted the ambiguities created by the new standard:

\footnotetext{
"Abusive" (or "hostile," which in this context I take to mean the same thing) does not seem to me a very clear standard - and I do not think clarity is at all increased [****13] by adding the adverb "objectively" or by appealing to a "reasonable person['s]" notion of what the vague word means. Today's opinion does list a number of factors that contribute to abusiveness, see ante, at 23 , but since it neither says how much of each is necessary (an impossible task) nor identifies any single factor as determinative, it thereby adds little certitude. As a practical matter, today's holding lets virtually unguided juries decide whether sex-related conduct engaged in (or permitted by) an employer is egregious enough to warrant an award of damages. One might say that what constitutes "negligence" (a traditional jury question) is not much more clear and certain than what constitutes "abusiveness." Perhaps so. But the class of plaintiffs seeking to recover for negligence is limited to those who have suffered harm, whereas under this statute " [***304] abusiveness" is to be the test of whether legal harm has been suffered, opening more expansive vistas of litigation.
}

Be that as it may, I know of no alternative to the course the Court today has taken. One of the factors mentioned in the Court's nonexhaustive list-whether the conduct unreasonably [*25] interferes with an employee's [****14] work performance — would, if it were made an absolute test, provide greater guidance to juries and employers. But I see no basis for such a limitation in the language of the statute. Accepting Meritor's interpretation of the term "conditions of employment" as the law, the test is not whether work has been impaired, but whether working conditions have been discriminatorily altered. I know of no test more faithful to the inherently vague statutory language than the one the Court today adopts. For these reasons, I join the opinion of the Court.

Despite his obvious frustration with the Court's new standard, Scalia could not think of anything better, so he joined the opinion. This is exactly the problem! The standard is unclear, and, therefore, the jury instructions are unclear, 
leaving juries to decide on their own if the conduct rises to the level of being unlawful.

To illustrate this problem, I perform an exercise in my Hospitality Law class while teaching the law of hostile environment. First, I put four columns on board labeled: (1) criminal, (2) tortious, (3) unlawful, and (4) uncool. Next I explain that if the conduct is a crime or so outrageous that it would be considered intentional infliction of emotional distress, it will be objectively severe or pervasive enough to be considered hostile or abusive. I then try to explain the difference between unlawful and uncool by asking a female student to play the role of an employee of a company for which I am the President. I instruct the student to say no to all my requests, while instructing the rest of the students to raise their hands at the point at which I have sexually harassed the student as defined by the law. I start by asking the student to lunch - the student says no. I then ask the student to lunch the next daythe student says no. From there I ask student to dinner, and then breakfast, lunch, and dinner for each subsequent day. Student hands begin to go up after the third request, and usually by three weeks of requests and rejections, all the students have raised their hands. The consistent results of this exercise are clear-even with jury instructions that detail the legal standard, there is no bright-line test for hostile environment.

\section{Same-Sex Sexual Harassment and the "Because of Sex" Problem}

As unclear as the Harris opinion was overall, it did, initially, lead to a somewhat clearer standard with regard to conduct and motivation. In his concurrence, Scalia used the term "sex-related" conduct. Prior to, and in the several years after Harris, courts split sexual harassment cases into two types of cases - sexual harassment and gender harassment. Sexual harassment dealt with overt sexual conduct. In such cases, no one asked for the harassers' motivation. Instead, the questions were what happened and how bad was it. Thus, the salacious conduct alleged against Harvey Weinstein and Kevin Spacey, would, if true, be unlawful. If the conduct was not sexual (e.g., yelling at one sex but not the other, requiring different levels of work performance based on gender), motivation became an issue.

When MacKinnon wrote that sexual harassment violated Title VII, she was focusing exclusively on supervising men harassing subordinate women. The early cases, including Meritor, followed that formula. For a time, cases could be classified as falling into two categories: sexual conduct and nonsexual conduct. In sexual conduct cases, the analysis was somewhat simple. If the conduct was either severe or pervasive and the conduct was sexual in nature, the courts presumed that the conduct was "because of sex" and found it unlawful. ${ }^{13}$ If the conduct was not sexual in nature, then the court needed to determine the motivation. If the employer was motivated by sex (meaning gender) the employee had a case for "gender harassment"; if gender was not the motivation, there was no cause of action. ${ }^{14}$ Indeed, the "equalopportunity jerk" defense became the tongue-in-cheek explanation for finding that a supervisor who created a hostile environment for employees regardless of sex (or any other protected class) did not violate the law. Post Meritor, there were a relatively small number of cases where supervising women were accused of harassing subordinate men. Uniformly, the courts held that these men had a cause of action.

In the mid-1990s, courts were faced with an onslaught of "same-sex" sexual harassment cases (i.e., a man harassing a man or a woman harassing a woman). Between 1992 and 1997, four different appellate courts faced the question of whether plaintiffs could make out a cause of action in samesex cases. The four circuits produced four different legal conclusions, prompting the Supreme Court to reconcile the issue in Oncale v. Sundowner Offshore Services. Before examining Oncale, an analysis of the four circuit court opinions that led to the decision is warranted.

The Fourth Circuit held that a same-sex sexual harassment claim would lie under Title VII if the harasser was gay. In Wrightson v. Pizza Hut of America, Inc., the plaintiff alleged that his supervisor graphically described homosexual sex to Wrightson and pressured him to have sex. ${ }^{15}$ The supervisor also rubbed his genital area against Wrightson's buttocks and often groped him. In finding for Wrightson, the Fourth Circuit held that same-sex Title VII claims are actionable only when the alleged harasser is homosexual and, therefore, presumably motivated by sexual desire. ${ }^{16}$

The Eighth Circuit held that there was a cause of action if only one sex suffered the alleged conduct. In Quick v. Donaldson Co., Inc., the employees engaged in an activity they described as "bagging." employee hitting and grabbing another employee. ${ }^{18}$ The plaintiff alleged that at least 12 different male coworkers bagged him. There was no evidence that female employees were ever bagged. The Eighth Circuit found for the plaintiff, reasoning plaintiffs may make out a claim for same-sex sexual harassment so long as only one of the genders suffered the conduct alleged. ${ }^{19}$ If, however, there was no disparate treatment (i.e., both men and women were treated similarly, even if poorly), then there was no cause of action. ${ }^{20}$

The Seventh Circuit held that there was a cause of action if the employee was treated poorly for failing to live up to a sexual stereotype. In Doe v. City of Belleville, two brothers, $\mathrm{J}$. and $\mathrm{H}$. Doe, alleged that they were physically threatened and verbally harassed at the construction site where they worked. ${ }^{21} \mathrm{~J}$. was called "fat boy" by his coworkers because he was overweight. The employees, including a supervisor, referred to H. as "fag" or "queer" on a daily basis. One employee, described by the court as a former marine of imposing stature, called H. his "bitch" and threatened to take H. "out to the woods" and "get him up the ass." The 
threats became physical when the former marine grabbed $\mathrm{H}$. by his testicles and announced, "Well, I guess he is a guy." Fearing escalation into outright physical assaults, the brothers quit their jobs. The Seventh Circuit rejected the argument that the sexual orientation of the harasser was relevant, and instead focused on the conduct endured by the plaintiffs. The court stated that conduct with sexual overtures is "because of sex" and, thus, if severe and pervasive, is unlawful..$^{22}$ Although some of the language in the case was broad, the true holding was narrower. The court relied on Price Waterhouse v. Hopkins ${ }^{23}$ to justify its finding for the plaintiffs. In Price Waterhouse, the Supreme Court held that an employer violates Title VII when an employee is denied a term or condition of employment because his or her appearance or conduct does not conform to stereotypical gender roles..$^{24}$ Like the plaintiff in Price Waterhouse, $\mathrm{H}$. was harassed because he did not conform to his coworkers' perception of being a man. Accordingly, the Seventh Circuit's holding can be viewed merely as an application of Price Waterhouse.

Finally, the Fifth Circuit in the clearest, but probably most troublesome, opinion held that same-sex claims are never actionable under Title VII. In Garcia v. Elf Atochem North America, a male plaintiff alleged that on several occasions his male supervisor approached him from behind, grabbed him, and made sexual motions. ${ }^{25}$ Garcia complained, and his employer informed the supervisor that any further incidents would result in termination. ${ }^{26}$ After the supervisor was reprimanded, no further incidents occurred between Garcia and his supervisor. ${ }^{27}$ Shortly thereafter, Garcia filed a charge of employment discrimination with the EEOC, alleging that he had been sexually harassed in violation of Title VII. The Fifth Circuit affirmed summary judgment in favor of the defendant for four different reasons. First, the harm was not redressible because the damages provisions of the Civil Rights Act of 1991 would not retroactively apply to the conduct, and equitable relief would be moot because Garcia still had his job. ${ }^{28}$ Second, the plaintiff failed to prove that any defendant was his "employer" for Title VII purposes. ${ }^{29}$ Third, even if one of the defendants could be his employer, that defendant took prompt remedial action calculated to end the harassment, and could, thus, avoid liability. ${ }^{30}$ Finally, the court flatly stated, "harassment by a male supervisor against a male subordinate does not state a claim under Title VII even though the harassment has sexual overtones." 31

\section{Oncale}

Two years later, the Fifth Circuit once again faced a samesex sexual harassment case. This time the plaintiff's case did not include the defects that formed the alternative holdings in Garcia: the requested relief was available, the plaintiff named the proper employer, and the employer did not respond to the complaints. Moreover, the conduct was severe and pervasive enough to withstand summary judgment, ${ }^{32}$ forcing the court to reach the issue of whether same-sex sexual harassment would support a claim under Title VII. Bound by the decision in Garcia, the Oncale court dismissed the case, but was troubled enough by its precedent to send up a flare:

This panel, however, cannot review the merits of Appellant's Title VII argument on a clean slate. We are bound by our decision in Garcia v. Elf Atochem, and must therefore affirm the district court. Although our analysis in Garcia has been rejected by various district courts, we cannot overrule a prior panel's decision. In this Circuit, one panel may not overrule the decision, right or wrong, of a prior panel in the absence of an intervening contrary or superseding decision by the Court en banc or the Supreme Court. ${ }^{33}$

The Supreme Court agreed to hear the case.

\section{Oncale Defines the Law}

In Oncale v. Sundowner Offshore Services, the U.S. Supreme Court resolved the split among the circuits by deciding that a plaintiff could make out a claim for sexual harassment as long as the harassing conduct was "because of sex. ${ }^{\prime 34}$ The Court did not hold, however, that sexual conduct presumptively meets this element. Instead, the Court held that the key issue is "whether members of one sex are exposed to disadvantageous terms or conditions of employment to which members of the other sex are not exposed." ${ }^{, 35}$ Thus, in the absence of evidence of the harasser's motivation, the employee must show that members of only one gender were subjected to the alleged conduct.

In Oncale, the Supreme Court discussed its reluctance to create a general civility code for the American workplace, and it acknowledged the differences in the ways men and women routinely interact with members of the same and opposite sex. According to the Court,

The prohibition of harassment on the basis of sex requires neither asexuality nor androgyny in the workplace; it forbids only behavior so objectively offensive as to alter the "conditions" of the victim's employment. Conduct that is not severe or pervasive enough to create an objectively hostile or abusive work environment - an environment that a reasonable person would find hostile or abusive - is beyond Title VII's purview. $^{36}$

To support this aspect of the holding, the Court focused on the "because of sex" requirement and made motivation the key element of case. In addition to being severe or pervasive, the conduct had to be "because of sex." The immediate reaction to the ruling was one of celebration by the plaintiffs' bar, who saw the holding as a victory for all workers, 
but specifically for homosexuals in the workplace. Indeed, the American Civil Liberites Union (ACLU) hailed Oncale as an important "for all Americans, gay or straight, male or female." $" 37$ The ACLU may have missed the point.

Although Oncale stayed true to Meritor and the statute by articulating the "because of sex" standard, the opinion fundamentally altered how the requirement would be operationalized. As stated above, in opposite-sex harassment cases before Oncale, courts presumed that the conduct was "because of sex" when the conduct was sexual in nature. ${ }^{38}$ In describing the "because of sex" standard, the Oncale Court and subsequent lower courts made it clear that the harasser's motivation was the key issue. Now, instead of simply proving that the conduct was severe or pervasive and sexual in nature - primarily objective inquiries - plaintiffs had to prove the harasser's subjective state of mind. The effect of this change was profound: First, it created a new defense- the equal-opportunity harasser defense. Second, it precluded a formerly viable theory of harassment based on sexual conduct demeaning to women. And third, because plaintiffs could be harassed or even assaulted for reasons other than their gender, courts looking to provide relief had to "find" a way to hold for the plaintiff.

\section{Equal-Opportunity-Harasser Defense}

In Holman v. Indiana, a husband and wife alleged that the same supervisor sexually harassed them. ${ }^{39}$ The wife alleged that the male supervisor sexually harassed her by touching her body, standing too close to her, asking her to go to bed with him, making sexual comments, and otherwise creating a hostile work environment based on sex. ${ }^{40}$ In addition, as a result of her refusal to perform the acts requested, the supervisor negatively altered her job-performance evaluations and otherwise retaliated against her for protesting his harassing behavior. ${ }^{41}$ The Holmans' complaint further alleged that the supervisor harassed the husband by "grabbing his head while asking for sexual favors." ${ }^{, 2}$ When the husband refused such requests, the supervisor retaliated by opening the husband's locker and throwing away his belongings. ${ }^{43}$

The court dismissed the case based on the equal-opportunity-harasser defense. To support its decision, the court stated that 'the 'equal-opportunity harasser' does not treat plaintiffs differently than members of the opposite sex ... [and] under current sex-discrimination theories, there is no discrimination when something happens to both sexes and not simply to one." 44 The court concluded by stating, "Simply put, the court concludes that, under current Title VII jurisprudence, conduct occurring equally to members of both genders cannot be discrimination 'because of sex" and is, therefore, not unlawful. ${ }^{45}$

Similarly, in Romero v. Caribbean Restaurants, Inc., the court dismissed the plaintiff's sexual harassment case because the supervisor exhibited the same harassing conduct to both men and women. ${ }^{46}$ Landrau, the plaintiff, alleged his supervisor made an explicitly sexual comment to Landrau. The supervisor then repeated the comment to a female employee shortly thereafter. Like in Holman, the Romero court dismissed the case pursuant to the equalopportunity-harasser defense. To support its decision, the court stated,

The record clearly shows that Figueroa [the supervisor] did not reserve his tasteless comportment for male employees, or that he treated male employees differently from female employees. In fact, it appears that Figueroa directed his most outlandish behavior, grabbing his genitals, as an insult to female employees. ${ }^{47}$

The court concluded, "While Figueroa's behavior and comments were often sexual in nature, and may have created an undignified or even unpleasant working environment, they were not discriminatory and thus not actionable under Title VII." ${ }^{48}$ In fact, according to Romero, the equal-opportunityharasser defense defeats both quid pro quo and hostile environment cases.

Prior to Oncale, conduct that was sexually demeaning to women and was severe or pervasive was often considered sexual harassment. For example, in Robinson v. Jacksonville Shipyards, Inc., the court held that a workplace plastered with pornographic pictures of women created a hostile environment even though those posting the pictures had no intent to offend female employees. ${ }^{49}$ Oncale's focus on motivation means that cases such as Robinson can no longer be considered unlawful harassment. ${ }^{50}$ Instead, if the motivation is not to demean either sex, the conduct, regardless of severity, pervasiveness, or the result, does not constitute sexual harassment. This holding flies in the face of the original purpose of sexual harassment law, contradicts significant academic literature, ${ }^{51}$ and, in the opinion of the authors of this article, contributes to the current problem manifested by the Weinstein phenomenon.

Oncale's reorientation of the "because of sex" standard on the harasser's motivation provides an inadvertent safe haven for objectionable conduct that should be unlawful. One paradigmatic fact pattern often presented to the EEOC and state human rights agencies is the "consensual affair gone sour" (CAGS). The law of CAGS was clear-a party to a consensual affair was not a member of a protected class and, thus, a supervisor could terminate or harass an ex-lover as long as the conduct was not sexual in nature. In other words, the supervisor could demote, terminate, and demean the ex-lover, but could not demand that the ex-lover resume the affair or engage in sexually charged conduct. ${ }^{52}$ The theory was that the supervisor was not acting because the employee was a woman. Instead, it was because she was that woman. If the conduct was sexual in nature or quid pro quo, 
however, that was per se unlawful, and the "that woman" argument would provide no defense. Post Oncale, however, the "that woman" argument works for all conduct - nonsexual conduct, conduct of a sexual nature, and even quid pro quo. One can see the logic, for example, in arguing, "I did not make suggestive statements because she was a woman, it was because she was the person who broke my friend's heart, and I want her to quit." More tellingly, the men in Oncale could say they did not sodomize Oncale because he was male - all the employees were men. Being sodomized at work is not sexual harassment in a unisex environment. Bringing it back to today's news, under the current law, it is possible that a court could find the conduct alleged against Kevin Spacey to not be unlawful because, it seems that Spacey may have harassed both men and women. ${ }^{53}$

\section{The Law Is Problematic}

The Holman and Romero decisions - that the equal-opportunity harasser does not violate Title VII-are logical, yet seemingly inappropriate extensions of the Supreme Court's holding in Oncale. If disparate treatment is required to prove same-sex sexual harassment, which is what Oncale stands for, then the equal-opportunity-harasser defense should emerge as the law of the land. This defense, we contend, should not be countenanced by Congress or the courts because it is detrimental to employees, employers, and society. No employer should want to have this type of harassment in the workplace. Whether the conduct is lawful, it reduces productivity, hurts morale, and may impose costs by, for example, increasing turnover and creating negative publicity that could destroy a business's value. Moreover, one would hope from an ethical/humanistic point of view, employers simply do not want to create/perpetuate this type of workplace. A legal standard that gives managers carte blanche to sexually harass employees (so long as they conduct themselves the same way with both sexes) creates a bizarre incentive. There is, however, a simple solution:

We need a law designed to prevent sexual harassment, and that law should have a simple standard-unwanted conduct of a sexual nature that is severe or pervasive should be per se unlawful. "Because of sex" motivation should no longer be relevant. Put simply, who cares why the men on the oil rig sodomized Joseph Oncale. The fact that they did it should be enough to violate the law.

Under this standard, employees would need to prove conduct - but not motivation-when bringing a claim for sexual harassment. And, such a standard would not create a general civility code, as feared by some writers. As Justice Scalia stated in Oncale, actionable conduct should still be "so objectively offensive as to alter the 'conditions' of the victim's employment." ${ }^{, 54}$ We believe that judges and juries can recognize horseplay for what it is. So too with "sexual" comments that are not intended to be interpreted literally.
Johnson v. Hondo, Inc. supports this principle..$^{55}$ In Johnson, two male coworkers hated each other. The way they chose to express their mutual disdain was to repeatedly call each other "punk,"56 "faggot," and "s.o.b.," and to say "I am going to make you s@*k my dick," and variants on that theme. ${ }^{57}$ It was clear from the context of the conversations that the speaker had no desire to engage in oral sex with his coworker. A panel of the Seventh Circuit, sitting after Doe but before Oncale, stated that conduct of a sexual nature violated Title VII if it was severe or pervasive. ${ }^{58}$ The court then dismissed the case, distinguishing the "facially sexual content of [the] remarks" from true sexual advances, and concluding the comments were mere "expressions of animosity or juvenile provocation." court also discussed whether the comments were directed at the Johnson because of his gender, the bulk of the analysis turned on the nature of the comments - whether they were sexual or not. The Hondo court properly applied the law to the facts. We believe that this standard should be the law of the land and the policy of employers. Similarly, quid pro quo ostensibly should be simple enough: An employer is guilty of quid pro quo harassment when the supervisor demands sex in exchange for a tangible job benefit (e.g., the job itself, a promotion, a raise). Before Oncale, no showing of motivation was required. Post Oncale, the equal-opportunity-harasser defense applied. In other words, demanding sex in exchange from job benefits is no longer unlawful if the harasser carries out such threats against both men and women. Under our simplified standard, there is no defense to a quid pro quo claim based on motivation, and there should not be.

Now that we have proposed a better standard, some additional questions arise: (a) who files claims, (b) what do they allege, and (c) when are employers liable. We begin with explaining the current law of employer liability.

\section{What Led Up to Ellerth/Faragher}

Meritor instructed to the lower courts to look to "agency principles" to determine liability. With no statute and little guidance, this was another recipe for confusion and competing incentives. By 1998, there was some general agreement among, and split between, the circuits with regard to various aspects of employer liability. The circuits agreed that employers were always liable for quid pro quo harassment, but could avoid liability for hostile environment cases. The theory behind this distinction was that in quid pro quo cases, the supervisor truly acted as an agent in the company because the threatened actions (e.g., hiring, firing, promoting, demoting) were company actions that could only be accomplished in the course of employment with the express or implied consent of the employer. Alternatively, a hostile environment could be created without any use of 
"company power." The supervisor could make comments, touch employees, without engaging in an official company action or speaking on behalf of the employer. Accordingly, all circuit courts agreed that employers were liable for quid pro quo, but not always for hostile environment.

With regard to hostile environment, there was a split between two theories. The minority of courts applied the quid pro quo reasoning and held that if the supervisor used agency power to create the hostile environment, then the company was liable. As an example, a company would be liable for the actions of a supervisor who used the power of the job to call a daily meeting with a subordinate and during the meeting commented on the employee's body, touched the employee, and required the employee to watch pornography. The majority of circuits employed the socalled negligence standard. Under the negligence standard, the employer was liable if it knew or should have known about the harassment. Thus, in the example described above, the employer would not be liable if it had a policy against sexual harassment informing the employees to complain and the employee did not.

As to be expected, plaintiffs' lawyers had a huge incentive to have their cases labeled as quid pro quo as opposed to hostile environment. The fact that the labels were both unclear and not mutually exclusive resulted in substantial litigation. The differences between the theories are substantial at the extreme, but not at the margin. For example, a supervisor who tells an employee, "sleep with me or you are fired," and then fires the employee who does not acquiesce has clearly engaged in quid pro quo harassment. The issue is not so clear when, for example, (a) the employee refuses to sleep with the supervisor and does not get fired, (b) the employee sleeps with the supervisor and does not get fired, (c) the employee quits and the supervisor now claims it was a joke, or (d) the threat is not as clear (e.g., "things would go better for you here if you wore more provocative clothes and were a little more accommodating") and the employee quits, acquiesces, or ignores and is not disciplined. Are any or all of the scenarios listed above quid pro quo? Are any or all the scenarios hostile environment? Courts have answered these questions differently. There are cases where each of these scenarios has been labeled quid pro quo, hostile environment, both, and neither. In Ellerth, the question before the court was

Whether a claim of quid pro quo sexual harassment may be stated under Title VII . . . where the plaintiff employee has neither submitted to the sexual advances of the alleged harasser nor suffered any tangible effects on the compensation, terms, conditions or privileges of employment as a consequence of a refusal to submit to those advances? ${ }^{60}$

The Court addressed the quid pro quo-hostile environment distinction, but not in the way the parties intended.
First, the Court seemingly defined quid pro quo when it stated, "Cases based on threats which are carried out are referred to often as quid pro quo cases, as distinct from bothersome attentions or sexual remarks that are sufficiently severe or pervasive to create a hostile work environment." Arguably, then, the Court's view was that, to be quid pro quo harassment, the threat must be carried out. Employees who acquiesced or were not disciplined for rejecting the advances could not make out a case of quid pro quo harassment. Thus, all cases with no discipline would be hostile environment cases. After acknowledging the quid pro quo-hostile environment distinction, the Court rejected the theory that this distinction was determinative of employer liability. ${ }^{61}$ Instead, the Court held that the key issue was whether the employee suffered a tangible loss. ${ }^{62}$ If so, the employer was liable. ${ }^{63}$ If not, the employer was liable but could escape liability if it could prove an affirmative defense. ${ }^{64}$ If the Court's statement, "cases based on threats which are carried out are referred to often as quid pro quo cases," is the definition of quid pro quo, then all quid pro quo cases result in strict vicarious liability for employers. In addition, employers would be liable when employees were not threatened, but still suffered tangible losses arising out of hostile environment. Thus, only hostile environment employees who did not suffer a tangible loss were subject to an affirmative defense.

The so-called Ellerth/Faragher defense has two prongs: (a) "that the employer exercised reasonable care to prevent and correct promptly any sexually harassing behavior" and (b) "that the plaintiff employee unreasonably failed to take advantage of any preventive or corrective opportunities provided by the employer or to avoid harm otherwise." 65 Upon any fair reading of this language, employers cannot avoid liability simply by proving that they acted reasonably, or even with the utmost care. ${ }^{66}$ They must also prove that the employee was unreasonable in some way. A fortiori, if an employee behaves properly - that is, he or she report the harassment and accept the employer's reasonable corrective action - the employer should never be able to establish prong two and will always be vicariously liable. ${ }^{67}$

\section{Research on the Ellerth/Faragher Defense}

To determine the effect of the Ellerth/Faragher defense, we performed two studies. In 2000, we studied the first 72 summary judgment cases decided under the Ellerth/Faragher defense. Almost all the cases in our first study were district court cases. ${ }^{68}$ In our 2014 study, we examined 131 appeals from cases where judges granted employers' motions for summary judgment. In addition to examining employer liability, our second study also reported information about the plaintiffs and claims. ${ }^{69}$ 


\section{Who Files Sexual Harassment Claims and What Do They Allege?}

Before reporting the results of the second study, it is important to set forth how we arrived at the data set. The 2000 study examined district court opinions because the law was only 18 months old and there were not enough cases from the United States Courts of Appeals to study. Indeed, the 2000 study looked at every case in which a court operationalized the Ellerth/Faragher defense and there were only two cases from courts of appeal.

The second study examined appeals of summary judgment motions. ${ }^{68}$ The main advantage of examining such cases is the de novo standard of appellate review for summary judgment determinations. ${ }^{69}$ Because the courts of appeal give no deference to the lower court's ruling under de novo review, the merits determination comes from the appeal court itself, rather than the lower court. To prevail on summary judgment, the moving party must show "that there is no genuine issue as to any material fact and that the moving party is entitled to a judgment as a matter of law." ${ }^{, 70}$ If a plaintiff employee sufficiently disputes the facts on any prong, the court cannot award summary judgment.

Case-selection method. The first thing we examined were characteristics of employers and employees involved in the cases. Most employers were from the private sector (71\%), and of the public-sector employers, roughly one sixth were federal and five sixths were state or local governments. In the private sector, distribution across the North American Industry Classification System (NAICS) industries was dispersed - the model industry was manufacturing (13\%), followed by retail $(11 \%)$, and accommodation and food services $(9 \%)$; there were no employers in the NAICS categories for agriculture, utilities, wholesale trade, management of companies, or other services. Plaintiffs were overwhelmingly female $(95 \%)$ and only about one quarter of the employees had been at the company for less than 1 year before filing the discrimination lawsuit; most employees' tenures were between 1 and 10 years. Finally, in $4 \%$ of cases, the EEOC represented the employee, and in $8 \%$ of cases, the case involved more than one employee-plaintiff.

Next, we examined the type of harassment and its duration. Eighty-four percent of cases involved workplace-only harassment. Harassment extended beyond the workplace in only $17 \%$ of cases, and in no cases was the harassment relegated to nonwork-related areas, though courts frequently explain that harassment need not occur within the workplace to be actionable. Table 2 lists the frequency of different forms of harassment. General sexually charged comments and sexual contact were the most frequently alleged behaviors, though these are also two of the lessspecific categories. Comments about the plaintiff's appearance, nonsexual contact, and requests for sexual favors were also very common. Less common were things such as love letters, written comments to the plaintiff, and displaying pornographic materials, as well as the most severe behavior, sexual assault. The duration of the harassment and the delay in reporting the harassment were also recorded. About half of the cases involved harassment that lasted up to 6 months, and another half between 6 months and 5 years, with very few cases of harassment lasting longer. The trend in the length of time it took the plaintiff to report the harassment is the same. This confirms the intuition that harassment, in the vast majority of cases, does not last long beyond the time an employee reports it to the employer.

In the 2017 world of harassment, the conduct alleged was closer to Franken than Weinstein with only $0.09 \%$ alleging sexual assaults. That is not to say that any percent of sexual assault is acceptable, but that number seems low give the current climate. The immediate thought is that employees do not report the assaults. It could be possible that women are more likely to report comments (73\%) than assaults, but we do not think that is why assaults make up such a low percentage of the cases. Employers simply do not want to litigate assaults. Employers and their lawyers are risk adverse. Litigating an assault has numerous downsides: (a) high risk of losing, (b) high risk of a large damage award, (c) bad publicity, and (d) negative effect on employee morale. Thus, employers settle "bad cases." In the fall of 2017 , settlements have been treated as somehow undermining the system and employers have been criticized for such. In fact, few, if any plaintiffs and, we contend, no plaintiffs' lawyer would prefer to litigate instead of settle. Our legal system is geared toward settlement and well fewer than 5\% of all cases filed in court reach verdict. Thus, the "really egregious" sexual harassment cases, rarely, if ever, are adjudicated by the courts.

\section{Employer Liability}

As stated above, the first study examined all federal district and circuit court cases deciding summary judgment motions on the merits of the Ellerth/Faragher defense in the 18 months after the Supreme Court issued its companion opinions. ${ }^{71}$ The initial reaction to the Ellerth/Faragher defense was that employers would be unable to prevail in sexual harassment summary judgment motions. The reason for this conclusion was twofold. First, it seemed that most courts would hold that the issue of whether the employer exercised reasonable care was a question for juries and, thus, employers would be unable to satisfy the first prong as a matter of law. Indeed, in the wake of Ellerth/Faragher, lawyers, human resource professionals, and other professionals contended that while satisfying the first prong would be difficult, employers could possibly achieve their desired goal if they had a policy, did training, and created a hotline. Second, 
employees who did not report could successfully argue that, based on the employers' practices, it was reasonable to not report and, thus, could avoid summary judgment. Third, as stated above, employees who "reported" could not be "unreasonable" and, thus, any employee who reported could avoid sexual harassment. Accordingly, our initial hypothesis was that summary judgment of sexual harassment claims was a thing of the past. Our results proved that we were woefully wrong.

First, employers satisfied the first prong in 42 of the cases $(59 \%)$. Second, employers prevailed in the 20 cases where it satisfied Prong 1 and the employee did not report. Third, employers prevailed in 18 of the 22 cases where the employer satisfied the first prong and the employee did Report. Accordingly, instead of summary judgment motions being a thing of the past, employers prevailed in 38 of the 72 motions (53\%). Two facts were most interesting. First, contrary to the conventional wisdom, employers only needed to have a "good policy"72 to satisfy Prong 1 . In fact, only one court stated that employers might need to have more (e.g., training, an 800 number). Second, employers prevailed in 18 of the 22 cases where the employer satisfied the first prong and the employee reported.

In our second study of 131 cases where the plaintiffs appealed the court granting the defendants' motions for summary judgment, the courts of appeals affirmed 92 cases. Thus, the employer failed to prevail in 39 cases. Of the 131 cases, the employee did not complain in 25 cases. The employer prevailed in 24 of those 25 cases. In the Fordham study, the employer prevailed in $100 \%$ of the cases in which the employee failed to report-the general consensus among the courts was that employees' subjective fears of retaliation did not absolve the employees of their duty to complain. Here, the employer prevailed in $96 \%$ of the cases where the employee failed to report. In the one case where the employee failed to report yet prevailed, Davis v. Team Electric Co., the employer was woefully deficient in its efforts to prevent or correct harassment. ${ }^{73}$ The court noted that there was no evidence the employer had an antiharassment policy or any way to avoid complaining to a harassing supervisor. And, the employer performed no investigation and took no action against the harassing supervisors. Although the employee did technically complain, she only complained to the harassing supervisors (which we coded as " 0 ",74). But the court stated, "[Defendant] has not shown that [plaintiff] failed to take advantage of any preventive or corrective opportunities that it offered." ${ }^{, 75}$ In other words, an employer's behavior can be so bad that an employee's failure to complain is not an unreasonable failure to avail oneself of preventive or corrective opportunities because, in effect, there are no such opportunities.

There were 106 cases where the employee did report. In the Fordham study, the employer prevailed in $84 \%$ of the cases where the employee reported. In the new study, the employer prevailed in $85 \%$ of cases where the employee reported. Both results fly in the face of Justice Thomas' dissenting opinion where he stated, "employers will be liable notwithstanding the affirmative defense, even though they acted reasonably, so long as the plaintiff in question fulfilled her duty of reasonable care to avoid harm." Justice Thomas' contention is the logical extension of a faithful application of the law. The question is, When does an employee fail to "fulfill [the] duty of reasonable care to avoid harm?" Clearly, not reporting constitutes such a failure in the vast majority of cases. In this study, there were seven cases where the employees failed to avoid harm by rejecting the employer's accommodation. For example, in Brenneman v. Famous Dave's of America, Inc., once the employee complained of harassment, the employer investigated the allegations and offered to transfer her to another store away from the harassing supervisor. ${ }^{76}$ Because the employee refused this offer and resigned instead, the court found the employee was unreasonable. ${ }^{77}$ Similarly, in Baldwin v. Blue Cross/Blue Shield of Alabama, the plaintiff resigned when, after complaining about harassment, her employer offered to keep her in the same position but provide counseling between her and the alleged harasser. ${ }^{78}$ The court held that refusing this "first step" in conflict resolution was unreasonable. ${ }^{79}$ Similarly, resigning or refusing to return to work after the employer disciplined or fired the harasser was found unreasonable. ${ }^{80}$ In one case, the employee was found unreasonable when she reported the harassment to a supervisor but specifically asked the supervisor not to commence an investigation for fear of reprisal. ${ }^{81}$ In another nine cases, the employee had a defect in reporting (e.g., the complaint was vague). This means there were 56 cases where the employee reported to the correct person, did not reject the employer's accommodation, and had no other defect. In all these cases, the employer still prevailed. How can this be? In each case, the court held that the report was untimely. This was similar to the Fordham study, where the employee's reports were held to be untimely in 12 of the 18 cases where the employee reported, but the employer prevailed. ${ }^{82}$

In some cases, there was a delay of 1 year or more between the first harassing action and the report. ${ }^{83}$ In other cases, however, the delay was a matter of months or even weeks. For example, in Nuris Guerra v. Editorial TelevisaUSA, Inc. ${ }^{84}$ the plaintiff, who began working on May 28, 1996, was harassed every day from her first week of work until she complained on June 20, $1996 .{ }^{85}$ In dismissing the case, the court held that the delay, combined with the employer's prompt and proper response, satisfied the second prong of the defense. ${ }^{86}$ Similarly, in Mirakhorli v. DFW Management Co. ${ }^{87}$ it was unclear whether the harassment began either 2 or 8 months before the plaintiff complained. ${ }^{88}$ The court was unconcerned with the discrepancy because it 
found a delay of either 2 or 8 months to be unreasonable as a matter of law. ${ }^{89}$ Finally, in Dedner v. Oklahoma, ${ }^{90}$ the plaintiff waited 3 months to report the harassment because she did not think the employer's procedures would be effective and because she thought the supervisor would stop the harassing behavior. ${ }^{91}$ Again, the court found the delay unreasonable and granted summary judgment. ${ }^{92}$

By relying on timeliness, courts have effectively eviscerated the second prong for at least one subset of cases. The oft-cited justification for finding a delay unreasonable is the employee's duty to report harassment before it becomes "severe or pervasive." ${ }^{.3}$ A fortiori, if an employee has let the harassment continue until it has become pervasive, the duration is unreasonable. By tacking the unreasonableness of a delay to the moment at which harassment becomes pervasive, courts effectively eliminate the second prong of the defense (at least with respect to harassment alleged to be pervasive, vs. severe).

In reality, none of these cases were untimely. Instead, in each of these cases, the employer exercised reasonable care to prevent and correct, and the court simply would not rule against a good-actor employer. At one level, we believe that the result-orientated holdings are the correct way to apply the law because the alternative exposes employers to an untenable scenario: (a) Employers must establish sufficient antiharassment policies and complaint procedures so they may satisfy Prong 1, (b) they prevail if the employee does not report, and (c) they lose if there was harassment and the employee complained. This creates two perverse incentives: (a) Employers should either make it difficult for employees to report (e.g., no 800 number) and/or (b) investigating employers should find that harassment did not exist because if a report eliminates the defense, the only way to escape liability is to conclude that no harassment existed. It is much preferable if employees have an incentive to encourage reports and discover the truth. The problem is that the defense as written still requires a finding of the employee being unreasonable. In response, courts try to "find" ways to make sexual harassment victims unreasonable to achieve the just result.

The current fix by the majority of courts is to create new law: Employers who exercise reasonable care to prevent harassment and react well to a complaint will prevail at summary judgment. To justify such a holding, courts will find the plaintiff untimely, and, therefore, unreasonable, regardless of whether the delay, if any, was reasonable and regardless of how much time it took to report. However, a minority of courts will hold true to law and find against the good-actor employer if the employee reported. Thus, there is no true legal precedent to follow, employers still have perverse incentives, and plaintiffs' lawyers have no guidance as to whether or not they should pursue a case.

Even more problematic is what the "new law" creates for sexual harassment victims. Judging the reasonableness of a complainant's actions creates numerous problems. Pursuing a sexual harassment complaint can be difficult. Regardless of the company's procedures, employees may wonder whether they are being overly sensitive by misinterpreting innocent banter, or whether they can resolve the issue without the angst and difficulty associated with pursuing a formal complaint. Although early complaints may pare down the harassment before it blooms to an unlawful level, it should not, however, be required to sustain a plaintiff's case through a defendant's summary judgment motion. Employees should not have to endure the stress of what results in an ostensible 2-month statute of limitations for harassment under which they be will be forced to complain before they are sure that the conduct is, or soon will be, unlawful or even inappropriate. Alternatively, what is more likely to result is that employees will not report soon enough, and lose more sexual harassment cases on summary judgment. ${ }^{94}$ This will lead to more complaints that may be dismissed as harmless. Such a scenario has two negative results: First, a harassment complaint can harm an alleged harasser's career and adversely impact his or her family life; second, a proliferation of unsubstantiated harassment complaints could fuel resentment and more discrimination in the workplace. There is, however, an easy solution to this problem.

The affirmative defense should drop the second prong. To avoid vicarious liability, employers must exercise reasonable care to prevent and to stop sexual harassment. Employers should not have to prove that the employee acted unreasonably. "Reasonable care" should consist of prescriptive measures that both prevent sexual harassment and encourage - or, at the very least, do not discourage - its reporting. In addition, "reasonable care" should also be measured by how an employer reacts to complaints of sexual harassment. ${ }^{95}$ Courts will be able to follow the law; employers will no longer have perverse incentives and will be rewarded for positive behaviors, and reporting employees will not be vilified to justify adverse holdings.

On its face, our proposed standard raises several questions that warrant examination. What happens to the employee who waits 3 months or even 3 years to complain? Under current law, the employer's liability ${ }^{96}$ is based on a determination by a judge or jury as to whether such a delay is reasonable. ${ }^{97}$ We advance a different approach, and contend that employers should be held liable for all harassment-whether the employee complained after 3 days or even 3 years - if the employer failed to respond to the complaint properly. Conversely, employers that properly respond to complaints should be able to avoid all liability. Employees would be under no undue time pressure to report harassment before they were ready, and an employer's liability would not be determined by an employee's decision on whether to report. 
Of course, our standard is not perfect. It does, however, improve the current rule, and it does so in a manner that satisfies the broader goals expressed in the Ellerth and Faragher decisions. First, our proposed approach eliminates the problem of rewarding employers for employing individuals who are reluctant to report harassment and penalizing employers for employing individuals who report harassment promptly. This is particularly significant because there is a strong argument, based on careful review of the cases applying Ellerth and Faragher, that employers aiming to avoid liability would be best served by not offering a hotline or other similar method of reporting harassment that is easy and anonymous. ${ }^{98}$ Along similar lines, a careful analysis of the case law reveals that employers would be well advised not only to scrap the anonymous reporting mechanisms but also to eliminate or discontinue so-called "sexual harassment training" programs for employees (but obviously not for managers) ${ }^{99}$ that go above and beyond the reasonableness necessary to win on an Ellerth or Faraghe motion. Moreover, the Ellerth and Faragher progeny create an incentive for employers to hire individuals who are unlikely to report harassment. In this era of advanced personality testing and easy access to personal background information, employers could invest in software programs aimed at screening out potential reporters. This is an undesirable use of resources that would be eliminated by our proposed standard.

Second, employees would not unintentionally undermine their claims when they, in good faith, delay reporting or inadvertently report to the wrong person. Instead, after employees report harassment, only two facts would matter: (a) whether the employer was notified of the alleged harassment and, if so, (b) whether the employer took the necessary and appropriate steps to correct the behavior. Employers would not have to fear that sexual harassment reports would automatically make their companies liable, and employees would not feel pressured to report before they are ready. Simply put, there are few logical reasons for courts to have to determine what constitutes a "reasonable" delay.

\section{Conclusion}

Sexual harassment law is at the forefront of our national discussion for numerous reasons and only an extremely myopic observer would contend that Meritor and its progeny, and Ellerth/Faragher and its progeny, are the only causes of the current focus on this problem. It is, however, clear that the law as developed by the courts is not serving the public interest. Congress needs to create a legal standard that defines sexual harassment and clarifies liability. We propose that motivation should be irrelevant in sexual harassment and that quip pro quo or hostile/abusive behavior that is severe or pervasive from an objective and subjective standpoint should be unlawful, regardless of whether the conduct was "because of sex." We also propose that employers who exercise reasonable care to prevent and correct harassment should not be liable, regardless of the reporting of the employee. Reasonable care, however, needs to be more than a policy and that training and other avenues of reporting should be required. For now, however, the law is almost clear-employers are best served by nonreporting employees and strong reactions. In the court of public opinion, however, liability is not the only issue to be concerned about. Employees need to ensure that harassment does not occur and that employees believe the reporting mechanisms are simple and the company's motives are pure. Accordingly, we propose that employers educate employees as to the law, educate them how to report, and be transparent about the process of investigation and correction.

Put more simply, our proposed standard will harmoniously incentivize employees and employers alike to report, prevent, and eradicate sexual harassment from the workplace. The conflicting incentives and confusing standards of the current law have repressed sexual harassment to the point creating the current Weinstein/Clinton/Trump monster.

\section{Declaration of Conflicting Interests}

The author(s) declared no potential conflicts of interest with respect to the research, authorship, or publication of this article.

\section{Funding}

The author(s) received no financial support for the research, authorship, or publication of this article.

\section{Notes}

1. See https://nypost.com/2017/11/04/top-chef-and-kitchenstaff-accused-of-sexual-harassment/.

2. See, for example, Gillian Hadfield, Rational Women: A Test for Sex-Based Harassment, 83 Calif. L. Rev. 1151, 1166 (1995) (discussing the Supreme Court's interpretation of Congressional intent embodied in Title VII's protection against sexual harassment in Meritor. Bank FSB v. Vinson, 477 U.S. 57, 64 (1986)); Michelle Angelone, Same-Sex Harassment Claims Under Title VII: Quick v. Donaldson Co. Breathes New Life Into the Post-Garcia State of the Law, 9 J. Law. \& Pub. Pol'y 61, 76-79 (1997) (discussing several courts' interpretation of Congressional intent underlying sexual discrimination). "Tangible losses" occur when there is a material change in employment, such as termination, failure to promote, demotion, or a change in benefits. See Ellerth, 118 S. Ct. at 2268-2269.

3. Catherine MacKinnon, Sexual Harassment of Working Women: A Case of Sex Discrimination (1979). See also: Kathryn Abrams, The New Jurisprudence of Sexual Harassment, 83 Cornell L. Rev. 1169 (1998) (discussing Professor MacKinnon's influential role in the development of sexual discrimination law). Yale University Press New Haven and London. Copyright 1979 Yale University.

4. McKinnon Id. at 1. See also Louis P. DiLorenzo \& Laura H. Harshbarger, Employer Liability for Supervisor Harassment After Ellerth and Faragher, 6 Duke J. Gender L. \& Pol'y 3 (1999). 
5. See, for example, Kristine A. Littleton, Feminist Jurisprudence: The Difference Method Makes, 41 Stan. Law. Rev. 751, (1989) (reviewing all of Professor MacKinnon's work and discussing its profound influence on legal doctrine and practice).

6. The EEOC Guidelines define quid pro quo harassment as "Unwelcome sexual advances, requests for sexual favors, and other verbal or physical conduct of a sexual nature. . . when (1) submission to such conduct is made either explicitly or implicitly a term or condition of an individual's employment, [or](2) submission to or rejection of such conduct by an individual is used as the basis for employment decisions affecting such individual. .." 29 C.F.R. \$1604.11(a)(1985).

7. See Henson v. Dundee, 682 F.2d 897 (1982): "Sexual harassment which creates a hostile or offensive environment for members of one sex is every bit the arbitrary barrier to sexual equality at the workplace that racial harassment is to racial equality. Surely, a requirement that a man or woman run a gauntlet of sexual abuse in return for the privilege of being allowed to work and make a living can be as demeaning and disconcerting as the harshest of racial epithets" at 902. See also Katz v. Dole, 709 F.2d 251, 254-55 (CA4 1983); Bundy v. Jackson, 205 U. S. App. D. C., at 444-54, 641 F.2d, at 934-44; Zabkowicz v. West Bend Co., 589 F. Supp. 780 (E.D. Wis. 1984).

8. 477 U.S. 57 (1986) aff'g sub nom Vinson v. Taylor, 243 U.S. App. D.C. 323, 753 F.2d 141 (1985).

9. See Rabidue v. Osceola Refining Co., 805 F.2d 611 (6th Cir. 1986), cert. denied 481 U.S. 1041 (1987).

10. Vance v. Southern Bell Telephone \& Telgraph Co., 863 F.2d 1503 (11th Cir. 1989).

11. Downes v. FAA, 775 F.2d 288 (Fed Cir. 1985).

12. Ellison v. Brady, 924 F.2d 872 (9th Cir. 1991).

13. In fact, as the law developed there were cases where the female employees were considered to have suffered harassment if they were exposed to sexual conduct (e.g., conversations, pornographic pictures) that was not directed at them, but was so pervasive that the complaining employee could not escape. See, for example, Petrosino v. Bell Atl., 385 F.3d 210 (2d Cir. 2004).

14. See Cline v. Gen. Elec. Capital Auto Lease, Inc., 757 F. Supp. 923, 931 (N.D. Ill. Feb. 2, 1991).

15. 99 F.3d 138 (4th Cir. 1996).

16. Id. at 143 .

17. 90 F.3d 1372, 1378-79 (8th Cir. 1996).

18. Id.

19. Id. at 1379 .

20. Id.

21. Doe v. City of Belleville, 119 F.3d 563, 570 (7th Cir. 1997).

22. See Id. at 576 and 577. See also: Andrews v. City of Philadelphia, 895 F. 2d. 1469 (3d Cir. 1990).

23. 490 U.S. 228 (1989).

24. Price Waterhouse, 490 U.S. 228. Hopkins was a senior manager at Price Waterhouse, a professional accounting partnership. After she was neither offered nor denied partnership and the partners refused to reconsider her for partnership, she sued Price Waterhouse, charging that it had discriminated against her on the basis of sex. The lower court ruled in Hopkins's favor, holding that Price Waterhouse had unlawfully discriminated against her on the basis of sex by consciously giving credence to some partners' comments about her that resulted from sex stereotyping. The Court of Appeals affirmed. Both courts held that an employer who has allowed a discriminatory motive to play a part in an employment decision must prove by clear and convincing evidence that it would have made the same decision in the absence of discrimination. Price Waterhouse could not carry this burden.

25. Garcia v. Elf Atochem North America, 28 F.3d 446, 448 (1994).

26. Id.

27. Id. at 448-49.

28. Id. at 450 .

29. Id. at 450-51.

30. Id. at 451 .

31. Id. at 451-52.

32. According to his lawyer, Nick Canady, Oncale's co-workers, including supervisory personnel, grabbed him, held him, unzipped their trousers and exposed themselves, and threatened to have sex with him. Oncale claimed he was in a shower when these same men got in the shower stall with him, restrained him, and sexually assaulted him using a bar of soap.

33. Oncale v. Sundowner Offshore Servs., Inc., 83 F.3d 118, 119 (5th Cir. 1996), rev'd, 523 U.S. 75 (1998).

34. Oncale v. Sundowner Offshore Services, 523 U.S. 75 (1998).

35. Id. at 80 .

36. Id. at 81

37. Jan Crawford Greenburg, Sex Suit Fallout Alarms Its Advocates, Chi. Trib., August 2, 1999.

38. For example, Winsor v. Hinckley Dodge, Inc., 79 F.3d 996, 1000 (10th Cir. 1996) (noting that "even if the motivation behind plaintiff's mistreatment was gender neutral," it could still form a basis for a claim of sexual harassment because the conduct itself was "sexually harassing behavior"); Burns v. McGregor Elec. Indus., Inc., 955 F.2d 559, 564 (8th Cir. 1992) ("[T]he harassment, because of its sexual nature, was based on [plaintiff's] sex.")

39. 24 F. Supp. 2d 909, 911 (N.D. Ind. 1998).

40. Id.

41. Id.

42. Id.

43. Id.

44. Id. at 912 .

45. Id. at 916.

46. 14 F. Supp. 2d 185, 190 (D.P.R. 1998).

47. Id. at 189 .

48. Id. at 190

49. 760 F. Supp. 1486, 1523 (M.D. Fl. 1991).

50. See Ocheltree v. Scollon Prod'ns, Inc., 308 F.3d 351, 359-60 (4th Cir. 2002).

51. Kathryn Abrams, The New Jurisprudence of Sexual Harassment, 83 Cornell L. Rev. 1169 (1998); Katherine Franke, What's Wrong with Sexual Harassment?, 49 Stan. L. Rev. 691 (1997); Vicki Schultz, Reconceptualizing Sexual Harassment, 107 Yale L.J. 1683 (1998).

52. See, for example, Huebschen v. Dep't of Health \& Soc. Servs., 716 F.2d 1167 (1983)

53. A CNN article stated Spacey: "targeted production staffers who were typically young and male." http://money.cnn. com/2017/11/02/media/house-of-cards-kevin-spacey-harassment/index.html. Assuming that typically does not mean 
always, then women could have been victims too and thus, the conduct would not be unlawful.

54. Oncale v. Sundowner Offshore Servs., Inc., 523 U.S. 75, 81 (1998).

55. 125 F.3d 408 (7th Cir. 1997).

56. The plaintiff contended the harasser used the word "punk" to mean "homosexual partner," as the slang is used in prison. Id. at 410, n. 1 .

57. Id. at $410-11$.

58. Id. at 415 .

59. Id. at 412-13.

60. Petition for a Writ of Certiorari at i, Burlington Indus., Inc., v. Ellerth, 524 U.S. 742 (Oct. 3, 1997), 1997 WL 33,485,655 (citation omitted).

61. Id. at 754 .

62. Id. at 764-65.

63. Id.

64. Id. at 765 .

65. Id.

66. Id. at 773 (Thomas, J., dissenting).

67. Id.

68. Don't Train your Employees and Cancel your "1-800" Harrassment Hotline: An Empirical Examination and Correction of the Flaws in the Affirmative Defense to Sexual Harassment Charges, 69 Fordham L. Rev. 165, March 2001.

69. When Rules Are Made To Be Broken, 109 Nw. U.L. Rev. 109, Fall 2014.

70. This study aimed to include the entire universe of court of appeals opinions evaluating the merits of the Ellerth/ Faragher defense in the summary judgment context. This was accomplished by performing a search on WestlawNext in the "Federal Courts of Appeal[s]" database using the following syntax: "summary judgment" \&, (sex! gender) $/ 1$ haras!, \& (ellerth faragher "118 s.ct. 2257" "524 u.s. 742" "118 s.ct. 2275 " "524 u.s. 775 "). These search terms should capture every case that cites or mentions Ellerth or Faragher and uses the terms "summary judgment" and "sexual harassment" (or variations).

These search terms are reasonably calculated to capture all the cases of interest. Admittedly, there may be cases that treat the merits of the Ellerth/Faragher defense that do not mention or cite Ellerth or Faragher, but such cases are likely rare. Rather, the search was intended to be overbroad; indeed, it returned 644 results. Irrelevant cases were discarded during coding, leaving only 131 relevant cases. Using circuit court opinions on Westlaw carries two main limitations. First, appeals represent a tiny fraction of all workplace sexual harassment disputes. In subsequent study we found that fewer than $13 \%$ of all EEOC charges are filed in court. Previous studies find that: (1) fewer than $25 \%$ result in a summary judgment ruling on the merits; (2) of those cases, employers prevail on fewer than $65 \%$; and (3) plaintiffs appeal fewer than $25 \%$. Since the EEOC receives approximately 7,000 sexual harassment cases each year, it stand to reason that approximately 900 are filed in court, about 200 summary judgment motions are filed, employers win 130, and the plaintiffs appeal 30 .

Second, appellate opinions available on Westlaw exhibit selection bias. Not all cases are published, and those that are published are not randomly selected. While many unpublished opinions are available on Westlaw, circuits vary in the degree to which they publicize unpublished opinions. In addition, unpublished opinions affirm pro-defendant grants of summary judgment far more often than published opinions. Thus, whatever the rate of affirmance observed in this study is, the true affirmance rate, especially in circuits that restrict unpublished opinions, is likely higher. Moreover, the data on the types of conduct and party demographics are limited by the constraints of Westlaw and Lexis.

71. See Hayut v. St. Univ. of N.Y., 352 F.3d 733, 743 (2d Cir. 2003).

72. Celotex Corp. v. Catrett, 477 U.S. 317, 322 (1986).

73. Sherwyn et al., supra note 69 , at 1266 .

74. We defined a good policy as being written, disseminated, and not forcing the employee to report to the harassing supervisor and, instead, having "alternative channels."

75. See 520 F.3d 1080 (9th Cir. 2008).

76. See supra Part III.B.3.

77. Davis, 520 F.3d at 1097.

78. 507 F.3d 1139, 1145-46 (8th Cir. 2007).

79. Id.; see also Harmon v. Home Depot USA Inc., 130 F. App'x 902, 905 (9th Cir. 2005) (finding a plaintiff unreasonable where she quit when the employer was attempting to work out a transfer); Wallace v. San Joaquin Cnty., 58 F. App'x 289, 291 (9th Cir. 2003) (finding a plaintiff unreasonable where she refused to cooperate in the investigation and refused to pursue a transfer)

80. 480 F.3d 1287 (11th Cir. 2007).

81. Id.

82. Collette v. Stein-Mart, Inc., 126 F. App'x 678, 686 (6th Cir. 2005); Thompson v. Naphcare, Inc., 117 F. App'x 317, 324 (5th Cir. 2004).

83. See Hardage v. Viacom Television Stations Inc., 417 F.3d 1177, 1188 (9th Cir. 2005).

84. It must be noted that in each of these cases the employer responded with reasonable care according to the court. See Montero v. Agco Corp., 192 F.3d 856, 863 (9th Cir. 1999); Wright v. Anixter, Inc., No. 98-17,164, 1999 U.S. App. LEXIS 19,962, at *6 (9th Cir. Aug. 12, 1999); Desmarteau v. Wichita, 64 F. Supp. 2d 1067, 1079-80 (D. Kan. 1999); Mandy v. Quad/Graphics, Inc., 49 F. Supp. 2d 1095, 111 (E.D. Wis. 1999); Guerra v. Editorial Televisa-USA, Inc., No. 97-3,670-CIV-Ungaro-Benages, 1999 U.S. Dist. LEXIS 10,082, at*32-*33, *38 (S.D. Fla. June 2, 1999); Mirakhorli v. DFW Mgmt. Co., No. 3:94-CV-1,464-D, 1999 U.S. Dist. LEXIS 9,344, at *24 n.16, *25 (N.D. Tex. May 24, 1999); EEOC v. Barton Protective Servs., Inc., 47 F. Supp. 2d 57, 61 (D.D.C. 1999); Hetreed v. Allstate Ins. Co., No. 96 C 2021, 1999 U.S. Dist. LEXIS 7,219, at*16-*18 (N.D. Ill. May 11, 1999); Dedner v. Oklahoma, 42 F. Supp. 2d 1254, 1259-60 (E.D. Okla. 1999); Madray v. Publix Super Markets, Inc., 30 F. Supp. 2d 1371, 1375 (S.D. Fla. 1998); Montero v. Agco Corp., 19 F. Supp. 2d 1143, 1146 (E.D. Cal. 1998); Marsicano v. Soc'y of Safety Eng'rs, No. 97C 7,819, 1998 U.S. Dist. LEXIS 14,314, at *21-*23 (N.D. Ill. Sept. 3, 1998).

85. See, for example, Hetreed, 1999 U.S. Dist. LEXIS 7,219, at*3. 86. No. 97-3,670-CIV-UNGARO-BENAGES, 1999 U.S. Dist. LEXIS 10,082 (S.D. Fla. June 2, 1999).

87. Id. at $* 5-* 6, * 12$. 
88. Id. at *32-*38.

89. No. 3:94-CV-1,464-D, 1999 U.S. Dist. LEXIS 9,344 (N.D. Tex. May 24, 1999).

90. Id. at $* 24$ n. 16 .

91. Id.

92. 42 F. Supp. 2 d 1254 (E.D. Okla. 1999).

93. Id. at 1260 .

94. Id. While a delay may be unreasonable as a matter of law to some courts, others have denied summary judgment motions so that a jury could decide if the plaintiffs' delays were reasonable. See Watts v. Kroger Co., 170 F.3d 505, at 507-08 \& n.1, 510 (5th Cir. 1999) (noting that reasonableness of plaintiff's one-and-a-half month delay was a question for the jury); Fall v. Indiana Univ. Bd. of Trs., 12 F. Supp. 2d 870, 884 (N.D. Ind. 1998) (noting plaintiff's three month delay).

95. For example, Burlington Indus. Inc. v. Ellerth, 524 U.S. 742, 764 (1998) ("To the extent limiting employer liability could encourage employees to report harassing conduct before it becomes severe or pervasive, it would also serve Title VII's deterrent purpose.”); Baldwin v. Blue Cross/Blue Shield of Ala., 480 F.3d 1287, 1307 (11th Cir. 2007) ("The genius of the Faragher-Ellerth plan is that the corresponding duties it places on employers and employees are designed to stop sexual harassment before it reaches the severe or pervasive stage amounting to discrimination in violation of Title VII.”).

96. An obvious potential domino effect is that courts might start requiring handbooks and other personnel policies on sexual harassment reporting procedures to specify that all reporting must be made within a certain number of weeks, or else employees risk losing their claims based on Ellerth and Faragher.
97. See Indest, 164 F.3d at 266

98. This scenario assumes, of course, that the employer's proscriptive measures constitute "reasonable care."

99. See Burlington Indus., Inc. v. Ellerth, 524 U.S. 742, 765 (1998).

100. Anecdotal evidence suggests that such hotlines connect callers to a human-resources specialist working in an office not associated with the reporting employee's office. This alleviates the fear that rumors will circulate about the harassee's report, and generally reduces the fear that other co-workers in the harassee's office will know of his or her complaining. In turn, the anonymous nature of such hotlines makes them extremely well-received, and they are generally an excellent avenue for employees to report alleged harassment.

101. Training managers should have no effect on the likelihood of employees reporting, but may prevent unlawful conduct.

\section{Author Biographies}

David Sherwyn is the John and Melissa Ceriale Professor of Hospitality Human Resources and professor of Law at the Cornell University School of Hotel Administration/SC Johnson College of Business. He is also the director of the Cornell Center for Innovative Hospitality Labor and Employment Relations.

Paul Wagner is a shareholder with the law firm of Stokes, Wagner. He is also and adjunct professor of law at the Cornell University School of Hotel Administration/SC Johnson College of Business. 